Centre for technology, innovation and culture P.O. BOX 1108 Blindern N-0317 OSLO Norway

Eilert Sundts House, $7^{\text {th }}$ floor Moltke Moesvei 31

Phone: +4722841600

Fax: +4722841601

http://www.tik.uio.no info@tik.uio.no

\title{
TIK WORKING PAPERS ON
}

Innovation Studies

No. 20100617

http://ideas.repec.org/s/tik/inowpp.html 


\title{
INNOVATION STRATEGIES AS A SOURCE OF PERSISTENT INNOVATION
}

Tommy H. Clausen****, Mikko Pohjola**, Koson Sapprasert* and Bart Verspagen*****

\author{
*Centre for Technology, Innovation and Culture (TIK), Norway \\ **Turku School of Economics, Finland (corresponding author, email: mikko.pohjola@tse.fi) \\ *** Nordland Research Institute, Norway \\ ****Maastricht University, UNU-MERIT, the Netherlands
}

\begin{abstract}
An important topic in the recent literature on firms' innovation is the question of whether, and to what extent, firms which innovate once have a higher probability of innovating again in subsequent periods. This phenomenon is called the 'persistence of innovation'. Although the literature has established that innovation persistence is indeed important from an empirical point of view, relatively little attention has been paid to identifying the reasons why this is the case. This study proposes that the differences in innovation strategies across firms are an important driving force behind innovation persistence, and analyses this issue using a panel database constructed from R\&D and Community Innovation Surveys in Norway. Empirical measures of various innovation strategies are identified by means of a factor analysis. A cluster analysis is used in addition to a dynamic random effects probit model to extend the methodology adopted by prior studies, for the purpose to not only examine innovation persistence, but also determine how this persistence is influenced by innovation strategies. The results support the idea that the differences in innovation strategies across firms are an important determinant of the firms' probability to repeatedly innovate. The study also distinguishes the effects of strategy differences on the persistence of product and process innovation in all firms, and within high-tech versus low-tech firms.
\end{abstract}

Keywords: Persistence of innovation, Firm heterogeneity, Innovation strategy, Panel data 


\section{Introduction}

An important issue in the recent literature on firm-level innovation is whether, and to what extent, firms which innovate once have a higher probability of innovating again in subsequent periods. This phenomenon, which may be referred to as 'innovation persistence', has been addressed by a number of empirical studies using Community Innovation Survey (CIS) data (for example, Duguet and Monjon, 2004; Peters, 2009; Raymond et al., 2006), as well as other types of data (mainly patents, for example, Geroski et al. 1997; Malerba and Orsenigo 1999; Cefis 2003). Innovation persistence is usually specified in the econometric sense by a model in which the probability of a firm innovating is explained by a variable which measures whether or not the firm had innovated in a previous period (i.e. the lagged dependent variable), as well as a number of control variables. If the lagged innovation variable has a positive and significant sign, this is interpreted as persistence within the context of innovation. This finding is supplied by many studies of innovation persistence.

The present study somewhat deviates from the existing literature on innovation persistence in the sense that it is not primarily interested in the traditional question of whether or not, and to what extent, innovation is persistent. Instead, this study strives to answer why some firms (do not) persistently innovate. The variables which influence this, such as whether or not a firm has an R\&D department, or whether or not it maintains cooperative relationships for innovation, are affected by the long-run strategic choices made by the firm (see, for example, Nelson and Winter 1982; Teece et al. 1997). In this study, these factors are referred to as the 'innovation strategy' of the firm, and this notion will be operationalised below. To the authors' knowledge, none of the prior studies in the "innovation persistence" tradition has explicitly analysed the strategic factors behind innovation persistence at the firm level. Therefore, the question pursued by the present study is to what extent do differences in innovation strategies across firms explain why some firms persistently innovate? This research question is in line with a recent review of the capability literature, which argues that prior studies have not, in general, analysed the relationship between the capabilities and resources of firms, nor have they evaluated how these influence "the persistence of above average performance" (Hoopes and Madsen, 2008:394).

Following evolutionary theory and strategic management research, it is a central tenet of the approach of this study that there are important differences between firms in terms of how they innovate, and that this leads to different innovation probabilities at the firm level. As 
discussed below, the differences between firms, i.e. innovation strategies, are measured by using the European-wide harmonised Community Innovation Survey (CIS) questions on innovation activities (for example, $\mathrm{R} \& \mathrm{D}$, marketing or design), information sources (for example, internal or external to the firm) and the major goals a firm seeks to achieve by innovating (for example, gaining market share or saving labour costs). This study proposes that these variables capture the major elements of a firm's tendency to persistently innovate. Following on logically from the desire to measure firm characteristics in a rather precise way, two major types of innovation are distinguished in the study, i.e. product and process innovation. Although some prior studies have examined the persistence of product and process innovation, none of them has examined the driving forces behind innovation persistence within these two categories. This is the main contribution of the study to the literature.

The study's focus on the strategic driving forces behind persistent innovation is in line with the recent literature on innovation studies, which have begun to conduct a longitudinal analysis of firms in order to identify persistent heterogeneity and its causes (Dosi et al., 2008). Where others in the field have focused on profit and productivity persistence (see Bottazzi et al., 2008, for an example), the focus of this study is persistent innovation (and its driving forces), which is considered to be a key factor of profit and productivity persistence. As such, the study fits comfortably within the recent "persistent heterogeneity" topic in innovation studies. The study uses a panel dataset, constructed on the basis of R\&D and CIS surveys from Norway, ${ }^{1}$ and adopts a dynamic random effects probit model (Wooldridge, 2005). This model is similar to that used in most recent studies which address innovation persistence based on CIS data (for example, Peters, 2009; Raymond et al., 2006). However, the present study contributes to the literature by extending the Wooldridge model in a simple way, which enables an examination of whether, and to what extent, different types of innovation strategies relate to innovation persistence. The econometric specification used, which includes innovation strategies, nests the approach used in previous studies as a special case. In other words, this method provides a natural way to incorporate the idea in evolutionary theory that firms are different and innovative in diverse ways, and that the ways in which firms innovate may influence their ability to persistently innovate.

\footnotetext{
${ }^{1}$ Innovation and R\&D survey data is widely used in innovation studies. See Laursen and Salter (2006), Reichstein and Salter (2006), Vega-Juardo et al. (2009), for recent examples.
} 
Following this introduction, Section 2 firstly provides a short overview of the previous empirical literature on innovation persistence, and subsequently looks at the particular mechanisms for the persistence of innovation at the firm level suggested by the literature. The section also discusses how this leads to the theoretical perspective of this study, which will guide its empirical model. Section 3 presents the data and analytical method, and the empirical approach to measure a firm's innovation strategies is explained in Section 4, while Section 5 presents the econometric results. The last section provides a summary, and ends by proposing some recommendations for further research.

\section{Theoretical Background and Prior Literature}

\subsection{Prior empirical research on innovation persistence}

After the first studies appeared in the 1990s, the issue of whether or not innovation is persistent at the firm level has been addressed by many quantitative papers, especially recently. Although the basic empirical setting and econometric models used differ across studies, innovation persistence has always been examined by including lagged innovation as a predictor of current and/or future innovation. The literature on innovation persistence uses two different types of indicators of innovation. On the one hand, some prior studies apply patent data and R\&D data, and on the other hand, more recent studies focus on questionnairebased measures of innovation (for example, the CIS and the like). Somewhat simplified, survey questions about product and process innovation are considered to be output-based measures of innovation, while $R \& D$ is an input, and patents are a measure of invention. Early studies on innovation persistence mainly used patent data, and these studies found low, or no clear-cut, persistence of innovation (Geroski et al., 1997; Malerba and Orsenigo, 1999; Cefis and Orsenigo, 2001; Cefis, 2003). More recently, panel datasets based on the CIS have been made available to researchers, and recent studies tend to be more positive about whether or not innovation is persistent when using this data.

Using a dynamic count panel data model to link past and current innovations (in terms of the number of patents and/or R\&D expenditure), Crepon and Duguet (1997) reported a high persistence of innovation among R\&D intensive firms in France. Duguet and Monjon (2004) and Rogers (2004) both estimated a cross-sectional probit model and found strong innovation persistence in French and Australian firms, respectively. Focusing on R\&D activities, Castillejo et al. (2004) examined the persistence of innovation in Spanish manufacturing 
firms by using a dynamic probit model and panel data. They found that the influence of past $R \& D$ experience on the current decision to undertake $R \& D$ was positive and significant. In a recent study of firms in the German service and manufacturing industries, Peters (2009) used a dynamic random effects binary choice model and panel data to examine the persistence hypothesis. Her findings showed a high persistence of innovation activities in both manufacturing and services. In the service sector, however, the effect of innovation in the previous period on innovation in the current period was smaller than it was in manufacturing. In another recent analysis of Dutch manufacturing firms, Raymond et al. (2006) examined innovation persistence separately for high-tech and low-tech sectors. They found that firms in the high-tech sector innovated persistently, while this was not the case for low-tech firms.

When patents, $R \& D$ expenditure or innovation expenditure are used as the main data source, it is hard (or impossible) to differentiate between process and product innovation. However, to do so seems important, because these two types of innovation are of quite a distinct nature. Process innovation often requires less technological advancement and strategic decisionmaking (Rosenberg, 1982; Tushman and Rosenkopf, 1992). It is also often related to learning-by-doing, and linked to innovation strategies which are believed to be less developed compared to strategies for product innovation (Cabral and Leiblein, 2001; Pisano, 1997). This is why process innovation and product innovation may be expected to show different levels of persistence. In literature which addresses the evolution of industries, process innovation is usually regarded as being persistent in relatively mature industries where the focus is more on creating new, more efficient production processes than on introducing new products (Klepper, 1997; Utterback, 1994). In other words, persistence is likely to vary between the two types of innovation according to different industries.

To the authors' knowledge, only one previous study by Flaig and Stadler (1994) has examined whether, and to what extent, process and product innovation are persistent at the firm level. They used a dynamic random effects probit model and found that firms were persistent in both product and process innovation, but that there was no dynamic cross effects between these types of innovation. In other words, innovation of one type in the previous period did not explain the current innovation of the other type.

Some studies have found low persistence in the innovation activity of firms. Examples include Geroski et al. (1997) who used data on patents as well as "major" innovations for the 
UK (and a duration dependence model), and Malerba and Orsenigo (1999), Cefis and Orsenigo (2001) and Cefis (2003) who analysed EPO (European Patent Office) patent application data for manufacturing firms in France, Germany, Italy, Japan, the UK and the US. However, patents are not the same as innovations (Smith, 2004). ${ }^{2}$ The discussion of the literature in the present study suggests that persistency studies which have used patents as a proxy for innovation tend to identify a low degree of innovation persistence, while studies using either R\&D or "output"-based measures of innovation tend to find a higher degree of innovation persistence within firms. Altogether, it is clear that innovation persistence is not a clear-cut phenomenon, and that it requires a more in-depth research setting which can facilitate an analysis of the driving forces of persistent innovation.

\subsection{Why is innovation persistent at the firm level?}

Previous research has identified three broad theories to explain why some firms are persistent innovators (and why others do not persistently innovate). The first line of reasoning is based on the idea that "success breeds success" (Nelson and Winter, 1982; Flaig and Stadler, 1994). This idea stresses that prior commercial success in the form of a successful innovation creates profits which can be invested in current and future innovation activities. Because of financial constraints related to the risky nature of R\&D and innovation (see Hall, 2002a, b for a survey of the literature which addresses this issue), retained profits and past commercial success in previous innovative activities are considered to be particularly important for the financing of (new) innovation projects.

A second line of reasoning argues that some firms become persistent innovators due to dynamic economies of scale and "learning-by-doing" (Arrow, 1962; Nelson and Winter, 1982; Dosi 1988). This may be the result of the very nature of knowledge itself, which is cumulative and used as an input to generate new knowledge. It is often argued (see, for

\footnotetext{
${ }^{2}$ To use patent data to analyse innovation persistence may be problematic, since patents are heavily criticised as being a wrong measure for innovation. With only some exceptions, such as in the biotechnology industry in which many firms try to obtain a patent as the way to commercialise what they have invented (i.e. to innovate), it would be more appropriate to treat a patent as an invention since to patent does not necessarily mean to innovate. This is because, for the sake of accuracy, according to Schumpeter $(1911,1942$; see also Fagerberg, 2004), innovation should refer to the action or process of putting a new idea or model into practice, i.e. the introduction of an invention in the form of a new product or process into the economic or social system. Moreover, for a firm to be registered to have patented in a patent database, it needs to win a patent/invention race and be the first to apply for a patent. The persistence (not) found in patent data may, therefore, refer only to the success (or failure) in winning the patent race on a persistent basis. This suggests that the analysis using patent data may end up representing a story about persistence of invention or inventive leadership, not that of innovation.
} 
example, Malerba and Orsenigo, 1996) that this is particularly important in some sectors where the knowledge base is very cumulative, implying that experience in R\&D makes firms more efficient in innovating. In addition, learning-by-doing may take the form of 'procedural knowledge', because a firm may simply learn from dealing with the various tasks or problems it faces. This method of learning also refers to the management of relationships with external partners, such as universities, which is closely related to the notion of learning by interacting (Lundvall, 1988; Jensen et al., 2007). Assuming that the depreciation rate of innovative abilities is small, Raymond et al (2006) explain that knowledge which has been used to produce past innovations can be used again in the making of current, or even future, innovations. This line of reasoning emphasises a firm's persistent innovation behaviour.

Based more or less implicitly on a linear view of innovation, the third and final line of reasoning argues that innovation persistence at the firm level can be explained by the largely sunk nature of R\&D costs (Sutton, 1991; Cohen and Klepper, 1996). From this perspective, R\&D is not an activity which can be easily discontinued one year, and started again in the next year, mainly because knowledge is embodied in the human capital of researchers. Thus, whether or not to invest in an R\&D laboratory is a long-term decision, and once that decision has been taken, the firm is expected to have a constant flow of innovation, rather than a oneoff. Thus, innovation becomes persistent.

Nevertheless, R\&D is not the only innovation input/source (Arundel et al., 2008; Leiponen and Helfat, 2010). Other inputs include external knowledge (for example, in the form of cooperation, alliances, or licensing; see Bodas Freitas et al., 2008; Laursen and Salter, 2006), and internal activities like design, marketing, training, etc. Intuitively, not all of these innovation sources are associated with the same strong level of persistence as R\&D. For example, buying a license could be a one-off activity, leading to a single innovation, and the training of employees could relate to a single innovation project. When innovation or knowledge can be bought in the marketplace (Arora et al, 2001), persistence may also be low. On the other hand, strategic alliances in which knowledge is jointly developed between firms (Duysters and Hagedoorn, 1996; Vonortas, 1997), user-producer interactions (Von Hippel, 1988; Jensen et al., 2007), or cooperation with universities and public research institutes (Mowery and Sampat, 2004; Nelson, 1993) may have important sunk costs and may, therefore, be more durable. 
From this perspective, the degree of innovation persistence observed in a particular firm depends on the specific mix of innovation inputs or sources the firm uses. This suggests that it is important to include variables which measure these inputs in a regression framework aimed at identifying or explaining innovation persistence. This proposition is the key element of the contribution of the present study. However, whether or not such an approach is feasible depends, to a large extent, on the degree to which these innovation inputs themselves can be considered as being exogenous at the level of the regressions. In other words, whether or not there is merit in attempting to explain innovation persistence depends on what is known about the background of the differences between firms which may relate to a varying degree of innovation persistence.

This study contends that, given that the data used has, at most, three observations (on innovation) per firm spanning a decade in total (see below), the differences between firms in terms of the choice of innovation inputs can indeed be considered as being largely exogenous. These differences will be measured at the outset of the 10-year period observed, and then it will be assumed that these observed differences explain innovation and persistence over the next observations. The (assumed) long-run nature of these differences between firms is the main reason for referring to them as 'strategic' differences, i.e. innovation strategies are spoken of as factors which may account for differences in innovation and innovation persistence across firms. The justification of this assumption, which may seem heroic to some, comes from two related fields of literature which have influenced the recent discourse on innovation, namely, evolutionary economics and strategic management. Evolutionary economics deals with the processes of variation, selection and retention (Aldrich, 1999; Nelson and Winter, 1982). It argues that firms possess a set of semistable routines in which they store factors which affect innovation, as well as other strategic factors of the firm's behaviour. Although these routines are subject to change, this does not often occur, and generally, any such changes are not radical (Nelson and Winter, 1982; Cyert and March, 1963; Levitt and March, 1988). Because the routines are not based on a decisionmaking model with rational expectations or full information, and because firms differ in respect of their pre-determined knowledge and resources, they imply a relatively large degree of firm heterogeneity which evolves only slowly under the pressure of market selection. In the words of Nelson and Winter (1982:14), “... routines play the role that genes play in biological evolutionary theory. They are a persistent feature of the organism and determine its possible behaviour". 
Strategic management literature identifies the notion of competencies or capabilities as explaining innovation and innovation persistence at the firm level (for example, see Penrose, 1959; Grant, 1996; Winter, 2003). Existing literature on competencies addresses the resources or capabilities firms need in order to successfully create and sustain a competitive advantage. Competencies related to innovation and change within a firm are sometimes referred to as dynamic capabilities (Teece et al., 1997). The theory states that firms need to create or acquire these dynamic capabilities in order to be able to successfully innovate in a changing competitive environment. Dynamic capabilities are "higher level" competencies which enable the firm to continually renew its resource and knowledge base in order to keep up with the demands of the market, and persistently innovate (Winter, 2003). What this discussion simply suggests is that firms have dynamic capabilities, and dynamic capabilities lead them to pursue different innovation strategies.

The stable nature of strategic firm behaviour is also stressed in strategic management literature (see Hoopes and Madsen, 2008, for a review). In this respect, the notion of inertia plays an important role. Similar to the idea of semi-stable routines, the concept of inertia is that a firm's strategy is stable, hard-to-change and persistent at the firm level (for example, see Helfat, 1994; Stuart and Podolny, 1996). Winter (2003) argues that firms may innovate even without a strategic focus, or develop innovations in a non-routine way by ad hoc problem solving. However, theory predicts that persistent innovation is not likely without a clear strategy backed up by the relevant capabilities, and this is reinforced, for example, by the interaction between the firm's knowledge base and its absorptive capacity. Firms with more (relevant) knowledge and a better developed absorptive capacity are in a better position to innovate (Cohen and Levinthal, 1989, 1990), but innovation itself reinforces absorptive capacity. This latter aspect is sometimes referred to in the literature as double loop learning (Argyris and Schon, 1978). This mechanism can be extended to the Open Innovation model (Chesbrough et al., 2006), which has recently been influential in strategic management literature. Firms which are more "open" in the innovation process reap higher sales and profits from new innovations (Laursen and Salter, 2006) ${ }^{3}$ which, in turn, may enable future innovation (i.e. the proposition of success breeds success, as discussed above).

\footnotetext{
${ }^{3}$ Laursen and Salter (2006) suggest that searching more widely and deeply for ideas or knowledge from external sources increases the benefits of open innovation. However, over-search (in terms of breadth and depth) may result in decreasing returns.
} 
In conclusion, it is argued that prior studies of innovation persistence have made a valuable contribution to innovation literature by demonstrating that firms which innovate once tend to innovate again in the future. However, prior empirical research can be perceived as only having had a loose coupling to theory, and no prior study in this literature has taken relevant theories into account when analysing why innovation is persistent at the firm level. In comparison, prior studies have focused on the explanatory power of the lagged innovation variable for current innovation, but this, in itself, cannot explain whether or not the persistent condition observed is caused by sunk costs, "success breeds success", learning by doing, or a combination of these. Therefore, this begs the question, "Why do some firms persistently innovate?"

The approach taken by the present study is to attempt to answer this question by relying on measuring a set of stable firm innovation characteristics, referred to as innovation strategies, and to use these to explain innovation in an econometric model. Because these innovation strategies are measured at the outset of the observed period (see below), a significant and positive impact on subsequent innovation occurrence would point to an element of innovation persistence which can be interpreted in the light of the theoretical perspectives discussed here. In other words, this study puts forth the argument that strategic differences across firms are persistent, and this helps to explain why some firms innovate persistently, while others do not.

\section{Data and Methodology}

The research in this study builds on a panel database created by Statistics Norway. The main objective of creating this database has been to track firms over time on key variables such as innovation, $\mathrm{R} \& \mathrm{D}$, employment and sales. The database contains information about all enterprises which have participated in at least one of the R\&D surveys conducted by Statistics Norway since 1993. These surveys are a census for firms with 50 or more employees, but a sample for smaller firms. As a consequence, large firms have a much higher probability of being included in several surveys rather than small firms. The R\&D survey is conducted every second year, and thus, the panel consists of waves of two years.

This study utilises part of the R\&D panel. The first year of the dataset used is 1997, in which this R\&D data was combined with data from the Community Innovation Survey for year 1997 (so called CIS2). The CIS2 questions on innovation applied in this study refer to the 
past three years, for example, the CIS2 survey asks whether or not the firm innovated in the period between 1995 and 1997. Because the surveys are conducted every two years, the innovation questions have an overlap of one year, and this may introduce an element of spurious persistence which is a potential significant problem (potentially much larger than the 10\% which Raymond et al. 2006 suggest). Therefore, the present study finds it necessary to create a sample without any overlap in the measurement period. In this study, the innovation variables used refer to the periods 1995-1997, 1999-2001, and 2002-2004. A survey covering the period between 1998 and 2000 does not exist, which is why the study is forced to leave a one-year gap between the first and second wave in the dataset. Because a lagged dependent variable is adopted as one of the regressors, the regressions use two observations per firm at most (this is the case for firms which are present in all 3 waves). Moreover, since the initial observation (data from the CIS 2) is used to measure the innovation strategies, the sample used in the regressions is limited to those firms which were present in the initial wave (the CIS 2). And because the questions about innovation in services are incompatible between the waves, the service sector is excluded from the dataset, i.e. the sample is limited to industry (mining, manufacturing, public utilities and construction).

Two dependent variables, namely, product innovation and process innovation, are employed one at a time. These variables are directly observed in the survey, and are binary. The value 1 for the product or process innovation variable indicates that the firm had one or more respective innovations (either product or process) during the 3-year period. Product and process innovations have been defined according to the so-called Oslo manual (see OECD/Eurostat, 2005), and refer to technological innovations which are new to the firm, but need not necessarily be new to the industry, or the world.

One of the control variables used in this study is firm size (from which larger firms are expected to have a higher probability to innovate, i.e. Schumpeter Mark II, 1942), and this is measured by the number of employees a firm has (as reported in the survey). The other control variables are industry dummy variables, time dummy variables, and innovation strategy dummy variables. Table 1 documents the summary statistics of the main variables used in the regressions, broken down by waves of the survey (wave 2 refers to the first observation used in the regressions, since wave 1 , which is the CIS 2 , is used only for lagged innovation variables). Both employment and $\ln ($ employment) are documented, but only the latter is used in the regressions. With an average number of 183 employees, the firms in this 
sample seem fairly large by Norwegian standards. This is a result of the fact that larger firms have a higher probability of being included in the sample, because of the aforementioned sampling method used by Statistics Norway. Also because of this sampling method, the average firm size in wave 3 is larger than in wave 2, i.e. those (larger) firms which are present in wave 3 are also present in the two previous waves (as opposed to the firms present in wave 2 , which need not be present in wave 3 ). In addition, the statistics in Table 1 demonstrate that the employment variable has a high standard error, which is the result of the skewed nature of this variable. In fact, there are a few very large firms in the sample, the largest of which has more than 11,000 employees.

Table 1 also reports that product innovation is more frequent (about $41 \%$ of all observations) than process innovation (about 34\%). Moreover, both forms of innovation are more frequent in wave 2 than in wave 3 , although this difference is much larger for process innovation (a drop from $38 \%$ to $26 \%$ ) than for product innovation ( $42 \%$ to $39 \%$ ).

Table 1. Descriptive statistics

\begin{tabular}{l|lll|lll|lll}
\hline & \multicolumn{3}{|c|}{ total } & \multicolumn{3}{|c|}{ wave=2 } & \multicolumn{3}{c}{ wave=3 } \\
& valid & & St. & valid & & St. & valid & St. \\
& $\mathrm{n}$ & Average & error & $\mathrm{n}$ & Average & error & $\mathrm{n}$ & Average & error \\
\hline Employment & 1510 & 183.4 & 490.0 & 905 & 170.6 & 435.4 & 605 & 202.6 & 561.6 \\
$\ln ($ Employment) & 1509 & 4.423 & 1.137 & 904 & 4.368 & 1.133 & 605 & 4.505 & 1.140 \\
Product innovation & 1476 & 0.409 & 0.492 & 905 & 0.420 & 0.494 & 571 & 0.391 & 0.488 \\
Process innovation & 1510 & 0.335 & 0.472 & 905 & 0.383 & 0.486 & 605 & 0.263 & 0.441 \\
\hline
\end{tabular}

Table 2 illustrates the transition probabilities for the innovation status of firms for both types of innovation. The sums of the values on the diagonal are an indication of persistence, as they indicate the fraction of firms which stay in the same class, being persistent innovators or persistent non-innovators (Cefis, 2003). These values are all high (above 0.5, with one exception), which suggests that persistence is indeed prevalent in the sample (but of course, this needs to be further tested in a regression model which includes control variables). However, process innovators seem to be less persistent. In both periods, firms which were initially process innovators have a relatively low probability of staying that way (compared to product innovators). In the second period (wave $2-3$ ), process innovators have an even 
larger probability of being non-process innovators in the next wave than remaining as process innovators $(0.6$ versus 0.4$)$.

The difference between the two cells in the second column of each matrix indicates the 'bonus' enjoyed by an initial innovator over an initial non-innovator in terms of innovation probability. Although these observed differences do not control for variables such as firm size and other (observed or non-observed) heterogeneity, they can serve as a rough benchmark of what to expect in the regressions. The observed differences range from $22 \%$ (process innovation in the first period) to $42 \%$ (product innovation in the second period).

Table 2. Transition probabilities

$$
\text { Period } 1 \text { (wave 1 - 2) }
$$

\begin{tabular}{|c|c|c|c|c|c|c|c|}
\hline \multicolumn{2}{|c|}{ Product innovation } & \multicolumn{2}{|c|}{ wave $=2$} & \multirow[b]{3}{*}{ wave $=2$} & & \multicolumn{2}{|c|}{ wave $=3$} \\
\hline & & No & Yes & & & No & Yes \\
\hline \multirow[t]{2}{*}{ wave $=1$} & No & 0.73 & 0.27 & & No & 0.80 & 0.20 \\
\hline & Yes & 0.34 & 0.66 & & Yes & 0.38 & 0.62 \\
\hline \multicolumn{2}{|c|}{ Process innovation } & \multicolumn{2}{|c|}{ wave $=2$} & \multirow{4}{*}{ wave $=2$} & & \multicolumn{2}{|c|}{ wave $=3$} \\
\hline \multirow{3}{*}{ wave $=1$} & & No & Yes & & & No & Yes \\
\hline & No & 0.71 & 0.29 & & No & 0.83 & 0.17 \\
\hline & Yes & 0.49 & 0.51 & & Yes & 0.60 & 0.40 \\
\hline
\end{tabular}

Note: The transition probabilities in each matrix are calculated for the firms that are present in the two successive waves considered (wave $1-2$, wave $2-3$ ).

Since the dependent variables employed are binary, a probit regression model is selected. This study follows the standard modelling procedure for analysing (innovation) persistence, i.e. the lagged dependent variable is included as an explanatory variable in the model in order to test the persistence hypothesis. The specific estimation model used is a dynamic random effects probit model. Obviously, in such a model, the probability of innovation is dependent on the past innovative history of the firm, and this can be traced back to the initial observation in the sample (wave 1). This initial observation proxies for otherwise unobserved firm's characteristics, and hence, as suggested by Wooldridge (2005), this initial observation is included, in addition to the lagged dependent variable. It is important to account for heterogeneity in this way, since otherwise the coefficient obtained for the lagged dependent variable may be biased (overestimated) (Raymond et al., 2006; Peters, 2009). Taking into 
account unobserved firm heterogeneity (by means of random effects), as well as the initial value of the dependent variable, provides a dynamic framework, in which a significant lagged dependent variable indicates true, not spurious, state dependence (Heckman, 1982).

In this study, a simple extension to the Wooldridge method (Wooldridge, 2005) is also devised to enable an analysis of the influence of innovation strategies on persistent innovation. Principally, the Wooldridge method incorporates an initial condition dummy variable which is coded 0 if firms did not innovate at $\mathrm{t} 1$ and 1 if firms innovated at $\mathrm{t} 1$, and this initial condition variable is fixed throughout the panel data analysis. The extension to this method is simply that subgroups of firms which innovated at $\mathrm{t} 1$ will be distinguished by using factor and cluster analyses. The CIS2 data used, which represents the time period t1 in the panel, contains various details about innovation in firms, and latent firms' strategies will be identified based on this information, by utilising a factor analysis. A cluster analysis will then categorise innovative firms at $\mathrm{t} 1$, based on how they score on the latent factors obtained from the factor analysis. This is important, because the results of the cluster analysis will help to identify subgroups of innovative firms which differ in their approach to innovation at $\mathrm{t} 1$. The identified clusters will be represented in the analysis by cluster dummies, where value 1 signals that an innovative firm at $\mathrm{t} 1$ belongs to the respective cluster (and not to the others). As the cluster analysis is undertaken using data of only innovative firms at $\mathrm{t} 1$, the cluster dummy variables can simply be combined and transformed back into the original dummy variable measuring the "initial innovation condition". Thus, factor and cluster analyses are two essential steps to be taken in order to examine whether, and to what extent, innovation strategies influence persistent innovation at the firm level over time.

\section{Measuring innovation strategies by factor and cluster analyses}

This section conceptualises innovation strategies, and categorises firms based on their strategies. The review in Section 2 suggests that firms use various knowledge sources and engage in a range of learning activities (for example, through different routines) in the innovation process. Thus, a first step is to identify latent variables or principle components which capture a variety of sources, objectives and activities related to innovation in firms. For this purpose, a factor analysis is undertaken on the relevant groups of variables extracted from the CIS2 questionnaire. The structure of the questionnaire is such that firms which do not report any product or process innovation are not allowed to answer the questions concerned, and these firms are excluded from the factor analysis. Therefore, the results 
reported in this section are based only on firms which have carried out some innovation activities.

\subsection{Results of factor analysis}

Table 3 reports the results of the factor analysis on the set of CIS2 questions which indicate the extent to which the sampled firms were active in different types of innovation activities. The particular factor pattern identified in the table suggests two broad innovation approaches, similar to the "make versus buy" option in technology sourcing. The "make" strategy includes a combination of internal and external $R \& D$, and the market introduction of innovation. The "buy" strategy incorporates reliance on machinery and equipment procurement, external technology, and training related to innovation. This result is in line with that of Veugelers and Cassiman (1999), which demonstrates that firms differ in how they use "make" and "buy" strategies.

\section{Table 3. Innovation activities}

\begin{tabular}{|c|c|c|}
\hline & Make & Buy \\
\hline $\begin{array}{l}\text {-Research and experimental development within the } \\
\text { enterprise (intramural R\&D) }\end{array}$ & $\mathbf{0 . 8 8}$ & -0.05 \\
\hline -Acquisition of R\&D services (extramural R\&D) & 0.82 & 0.00 \\
\hline $\begin{array}{l}\text {-Acquisition of machinery and equipment linked to } \\
\text { product and process innovations }\end{array}$ & -0.18 & 0.72 \\
\hline $\begin{array}{l}\text {-Acquisition of other external technology linked to } \\
\text { product and process innovations }\end{array}$ & 0.09 & 0.65 \\
\hline -Market introduction of technological innovations & 0.52 & 0.32 \\
\hline -Training directly linked to technological innovations & 0.12 & 0.71 \\
\hline
\end{tabular}

Note: $57 \%$ of total variance explained by the two factors; principal components factoring with oblique oblimin rotation, $\mathrm{chi}^{2}(15)=828.71$, Prob. $>\mathrm{chi}^{2}=0.00$, Numbers in bold indicate moderate to high factor loadings.

Table 4 illustrates the results of a second factor analysis, which aimed to identify latent factors in relation to the objectives of firms for innovation. It is assumed that firms differ in terms of innovation goal setting, and that this difference will enable the estimate to detect the factors which account for firm heterogeneity in the innovation process. According to the 
results, the common goals can be broadly categorised into a "production" dimension (reducing inputs and costs, while improving quality and satisfying standard requirements), and a "market" dimension (competing with better and more products).

Table 4. Innovation Objectives

\begin{tabular}{lll}
\hline & Production & Market \\
\hline -Replace products being phased out & 0.20 & $\mathbf{0 . 5 3}$ \\
-Improve product quality & $\mathbf{0 . 4 6}$ & 0.32 \\
-Extend product range & -0.06 & $\mathbf{0 . 8 2}$ \\
-Open up new markets or increase market share & -0.01 & $\mathbf{0 . 8 1}$ \\
-Fulfil regulations, standards & $\mathbf{0 . 5 9}$ & 0.05 \\
-Reduce labour costs & $\mathbf{0 . 7 2}$ & -0.11 \\
-Reduce materials consumption & $\mathbf{0 . 7 5}$ & 0.13 \\
-Reduce energy consumption & $\mathbf{0 . 8 3}$ & 0.01 \\
-Reduce environmental damage & $\mathbf{0 . 7 7}$ & -0.11 \\
\hline
\end{tabular}

Note: $53 \%$ of total variance explained by the two factors; principal components factoring with oblique oblimin rotation, $\mathrm{chi}^{2}(15)=828.71$, Prob. $>\mathrm{chi}^{2}=0.00$, Numbers in bold indicate moderate to high factor loadings.

Following the discussion in Section 2, different types of knowledge sources used in a firm's innovation process are also of interest. Therefore, a factor analysis was undertaken on the set of CIS2 variables which provide such information. The results indicated in Table 5 suggest the presence of three main characteristics or functions of sources of information used by the firms for innovation. The first is labelled "Science", and captures information from universities, research institutes, patents and, to a lesser extent, from computer networks and consultants. The second is labelled "Industry", and includes many sources within industry (including the firm's internal sources, customers, and competitors). The third is labelled "Opportunistic", and refers to the fact that this factor includes a number of sources which require relatively little effort on behalf of the firm which adopts them (suppliers of equipments, journals, professional conferences, fairs and exhibitions). 
Table 5. Sources of information for innovation

\begin{tabular}{llll}
\hline & Science & Industry & Opportunistic \\
\hline -Sources within the enterprise & 0.15 & $\mathbf{0 . 5 8}$ & -0.26 \\
-Competitors & -0.05 & $\mathbf{0 . 6 7}$ & 0.23 \\
-Clients or customers & -0.02 & $\mathbf{0 . 8 1}$ & -0.06 \\
-Consultancy enterprises & $\mathbf{0 . 4 1}$ & 0.12 & 0.24 \\
-Suppliers & -0.02 & -0.15 & $\mathbf{0 . 8 1}$ \\
-Universities & $\mathbf{0 . 8 6}$ & -0.04 & -0.02 \\
-Non-profit research institutes & $\mathbf{0 . 8 6}$ & -0.12 & 0.01 \\
-Patent disclosures & $\mathbf{0 . 6 4}$ & 0.24 & -0.08 \\
-Professional conferences, journals & 0.34 & 0.07 & $\mathbf{0 . 5 5}$ \\
-Computer information networks & $\mathbf{0 . 5 3}$ & 0.23 & 0.21 \\
-Fairs, exhibitions & -0.00 & 0.38 & $\mathbf{0 . 6 0}$ \\
\hline
\end{tabular}

Note: $55 \%$ of total variance explained by the three factors; principal components factoring with oblique oblimin rotation, $\mathrm{chi}^{2}(15)=828.71$, Prob. $>\mathrm{chi}^{2}=0.00$, Numbers in bold indicate moderate to high factor loadings.

\subsection{Identifying innovation strategies by means of hierarchical cluster analysis}

In order to identify the innovation strategies of the sampled firms, the results obtained from the factor analysis were used in a subsequent cluster analysis. Clustering was undertaken on the factor scores for the seven principal components documented in the previous three tables. The clustering procedure used was a hierarchical clustering, in which each firm was initially located in a separate cluster (so that the initial number of clusters was simply the total number of firms), and then the two most similar clusters were joined together sequentially at each step. Ward's method was adopted as the linkage function. Empirical validation was based on the agglomeration schedule of the hierarchical cluster process. The Calinski/Harabasz pseudo-F stopping rule was used, which indicated the solution to be between 2 to 5 clusters. Although the general custom is to report only a single cluster solution, in order to decrease the subjectivity of the analysis, and because there is no theoretical reason for expecting a single solution, a range of cluster solutions was opted for use. The four cluster solutions are reported in descending order, from five to two (as mentioned above, two of the most similar clusters were combined at each step). Table 6 documents the average factor scores in each of the clusters in different cluster solutions. Since the factor scores are standardised variables with a mean of zero and a standard 
deviation of one, a positive (negative) number in the table indicates an above (below) average result.

Table 6. Hierarchical Cluster Analysis

\begin{tabular}{|c|c|c|c|c|c|c|c|c|}
\hline & Make & Buy & $\begin{array}{l}\text { Produc- } \\
\text { tion }\end{array}$ & Market & Science & Industry & $\begin{array}{l}\text { Oppor- } \\
\text { tunistic }\end{array}$ & $\begin{array}{l}\mathrm{N} \\
(\%)\end{array}$ \\
\hline \multicolumn{9}{|l|}{ 5-Clusters } \\
\hline $\begin{array}{l}\text { Strategy } 1 / 5 \\
\text {-Supplier-based } \\
\text { Strategy } 2 / 5 \\
\text {-Ad Hoc } \\
\text { Strategy } 3 / 5 \\
\text {-Market-driven } \\
\text { Strategy } 4 / 5^{*} \\
\text {-R\&D intensive } \\
\text { Strategy } 5 / 5^{*} \\
\text {-Science-based }\end{array}$ & $\begin{array}{l}-0.71 \\
-0.84 \\
0.09 \\
1.17 \\
0.39 \\
\end{array}$ & $\begin{array}{l}0.34 \\
-0.36 \\
-0.47 \\
1.15 \\
-0.43 \\
\end{array}$ & $\begin{array}{l}0.11 \\
-0.68 \\
-0.55 \\
0.52 \\
0.41 \\
\end{array}$ & $\begin{array}{l}0.04 \\
-1.70 \\
0.35 \\
0.67 \\
-0.11 \\
\end{array}$ & $\begin{array}{l}-0.47 \\
-0.76 \\
-0.55 \\
0.83 \\
0.95 \\
\end{array}$ & $\begin{array}{l}0.01 \\
-1.67 \\
0.17 \\
0.71 \\
0.09 \\
\end{array}$ & $\begin{array}{l}0.54 \\
-0.34 \\
-0.91 \\
0.46 \\
0.20 \\
\end{array}$ & $\begin{array}{l}271 \\
(28.3) \\
85 \\
(8.9) \\
240 \\
(25.1) \\
129 \\
(23.5) \\
231 \\
(24.2) \\
\end{array}$ \\
\hline \multicolumn{9}{|l|}{$\begin{array}{l}\text { 4-Clusters } \\
\text { (5-Clusters with } \\
1 \text { restriction) }\end{array}$} \\
\hline $\begin{array}{l}\text { Strategy } 1 / 4 * \\
\text {-Supplier-based } \\
\text { Strategy } 2 / 4 * \\
\text {-Ad hoc } \\
\text { Strategy } 3 / 4 \\
\text {-Market-driven } \\
\text { Strategy } 4 / 4 \\
\text {-High-profile }\end{array}$ & $\begin{array}{l}-0.71 \\
-0.84 \\
0.09 \\
0.67\end{array}$ & $\begin{array}{l}0.34 \\
-0.36 \\
-0.47 \\
0.14\end{array}$ & $\begin{array}{l}0.11 \\
-0.68\end{array}$ & $\begin{array}{l}0.04 \\
-1.70 \\
0.35 \\
0.17\end{array}$ & $\begin{array}{l}-0.47 \\
-0.76 \\
-0.55 \\
0.91\end{array}$ & $\begin{array}{l}0.01 \\
-1.67 \\
0.17 \\
0.31\end{array}$ & $\begin{array}{l}0.54 \\
-0.34 \\
-0.91 \\
0.29\end{array}$ & $\begin{array}{l}271 \\
(28.3) \\
85 \\
(8.9) \\
240 \\
(25.1) \\
360 \\
(37.7)\end{array}$ \\
\hline \multicolumn{9}{|l|}{$\begin{array}{l}\text { 3-Clusters } \\
\text { (5-Clusters with } \\
2 \text { restrictions) }\end{array}$} \\
\hline $\begin{array}{l}\text { Strategy } 1 / 3^{*} \\
\text {-Supplier-based } \\
\text { Strategy } 2 / 3^{*} \\
\text {-Market-driven } \\
\text { Strategy } 3 / 3 \\
\text {-High-profile }\end{array}$ & $\begin{array}{l}-0.74 \\
0.09 \\
0.67\end{array}$ & $\begin{array}{l}0.17 \\
-0.47 \\
0.14\end{array}$ & $\begin{array}{l}-0.08 \\
-0.55 \\
0.45\end{array}$ & $\begin{array}{l}-0.38 \\
0.35 \\
0.17\end{array}$ & $\begin{array}{l}-0.54 \\
-0.55 \\
0.91\end{array}$ & $\begin{array}{l}-0.40 \\
0.17 \\
0.31\end{array}$ & $\begin{array}{l}0.33 \\
-0.91 \\
0.29\end{array}$ & $\begin{array}{l}356 \\
(37.2) \\
240 \\
(25.1) \\
360 \\
(37.7)\end{array}$ \\
\hline \multicolumn{9}{|l|}{$\begin{array}{l}\text { 2-Clusters } \\
\text { (5-Clusters with } \\
3 \text { restrictions) }\end{array}$} \\
\hline $\begin{array}{l}\text { Strategy } 1 / 2 \\
\text {-Low-profile } \\
\text { Strategy } 2 / 2 \\
\text {-High-profile }\end{array}$ & $\begin{array}{l}-0.41 \\
0.67\end{array}$ & $\begin{array}{l}-0.09 \\
0.14\end{array}$ & $\begin{array}{l}-0.27 \\
0.45\end{array}$ & $\begin{array}{l}-0.08 \\
0.17\end{array}$ & $\begin{array}{l}-0.54 \\
0.91\end{array}$ & $\begin{array}{l}-0.17 \\
0.31\end{array}$ & $\begin{array}{l}-0.17 \\
0.29\end{array}$ & $\begin{array}{l}596 \\
(62.3) \\
360 \\
(37.7)\end{array}$ \\
\hline
\end{tabular}

* denotes the two strategies/clusters that join together in the subsequent stage. 
The results begin with the 5-cluster solution. The Supplier-based strategy has high scores specifically on "buy" and "opportunistic", which suggests that these firms mainly rely on suppliers (of machinery and equipment) for their innovation. The Ad hoc strategy refers to the group of firms which has below-average (negative) scores on all factors. This strategy refers to undertaking innovation on an ad hoc basis (Winter, 2003), without particular reference to the strategic factors identified. The Market-driven group scores positive on "market" and "industry", and, to a lesser extent, on "make", which implies that firms in this group tend to seek knowledge from the industry for their innovation process, aiming to make more and better products to compete in the market. The R\&D intensive strategy represents a group of firms which are active in all of the aspects of innovation considered, but especially stand out with higher scores on both external and internal R\&D factors, "make" and "buy". The fifth group is called Science-based innovation strategy, since this group scores particularly high on "science" and "make", i.e. they are firms which utilise scientific knowledge and undertake internal R\&D.

In the 4-cluster solution, the Science-based and R\&D intensive groups are merged. This combined group (High-profile) still scores higher than average on all factors, but now more substantially on "science". In the next phase (the 3-cluster solution), the Ad hoc group is combined with the Supplier-based group, which, at this point, turns to have negative scores on all factors, except "buy" and "opportunistic". Here, the Supplier-based group seems to refer to firms which depend very little on themselves, but heavily on their suppliers. Finally, the 2-cluster solution distinguishes the High-profile and Low-profile groups of firms. The move to this stage merges the Supplier-based and Market-driven group into one with low scores on all factors, i.e. Low-profile (similar in meaning to the Ad hoc strategy identified above, but not in scale or membership).

The hierarchical nature of the clusters (i.e. at each transition between two levels, two clusters are combined) can, in the econometric context, be represented as being a set of restrictions on the coefficients in the estimated model. For example, the five strategies (clusters) will be represented by five dummy variables (the non-innovators being the reference category). The move to four strategies (clusters) can then be represented by the restriction that two of these dummy variables (R\&D intensive and Science based) carry the same coefficient. A similar logic applies to each "transition" to a lower number of strategies (e.g. four clusters is 
equivalent to five clusters with one restriction, and three clusters is equivalent to five clusters with two restrictions).

\section{Econometric Results}

The econometric exercise estimates a probit model for two dependent variables, namely, product innovation and process innovation. The first model (Table 7) examines the persistence of innovation by taking into account the lagged dependent variable and initial innovation as a way to account for firm heterogeneity, but does not yet include the innovation strategy variables. This is the model which has been used in the literature so far (e.g. Peters, 2009).

Table 7. Basic model

\begin{tabular}{l|lll|lll}
\hline & \multicolumn{3}{|l|}{ Product innovation } & \multicolumn{3}{l}{ Process innovation } \\
& Coeff. & St. Error & & Coeff. & St. Error & \\
\hline Initial innovation & & & & & \\
(Innovation at $\left.t_{1}\right)$ & 0.551 & 0.248 & $* *$ & 0.166 & 0.162 & \\
Lagged innovation & 0.436 & 0.213 & $* *$ & 0.323 & 0.171 & $*$ \\
Size & 0.277 & 0.053 & $* * *$ & 0.212 & 0.041 & $* * *$ \\
Industry dummies & & Yes & & & Yes & \\
\hline Rho & 0.266 & 0.143 & $* *$ & 0.106 & 0.134 & \\
BIC & 1782.2 & & & 1871.6 & & \\
No. of Observations & 1475 & & & 1509 & & \\
No. of firms & 910 & & & 910 & \\
average observation per firm & 1.6 & & & 1.7 & \\
\hline
\end{tabular}

$*, * *, * * *$ denote significance at the 10,5 and $1 \%$ level, respectively.

Both forms of innovation appear to be persistent, as indicated by the positive and significant sign of the lagged innovation variable in both cases. In the case of product innovation, the persistence effect is stronger and more significant, and the initial innovation is also significant, which further adds to the persistence result. In terms of process innovation, the initial innovation variable is not significant, and the lagged innovation has a lower estimated coefficient, which is only significant at the $10 \%$ level. Firm size is strongly significant in both cases, although the effect of size is weaker (but still sizable and very significant) in the case of process innovation. The contribution of unobserved firm heterogeneity to the total variance 
(rho) is significant in product innovation, in which case it accounts for about a quarter of the total variance.

The study proceeds by including the innovation strategy dummy variables in the equation instead of the initial innovation, in an attempt to account for the strategic differences between the firms which were argued (in Section 2) to be related to innovation probability and innovation persistence. It should be noted that the model of Table 7 is nested in this new specification, since firms which do not engage in innovation activities (at $t=1$ ) will show a zero value on all innovation strategy variables. Therefore, they are the baseline group, as they were in Table 7. One dummy is used for each innovation strategy, so that the specification of Table 7 corresponds to a case in which all of the coefficients of the innovation strategy dummy variables are equal to each other. It should also be noted that, as discussed above, the set of restrictions on the coefficients (applied to the results in Table $8-11$ ) is related to the different levels in the hierarchical cluster analysis which was used to identify innovation strategies. In this sense, using less innovation strategies corresponds more closely to the basic specification in the literature.

The reference to such restrictions is useful due to the fact that this study faced a choice about which level of the hierarchical cluster analysis to use. In dealing with this, the study opted to try all cluster solutions (in the range of $2-5$ clusters), and then chose the one which minimised the Bayesian Information Criterion (BIC) statistic. The BIC is a common criterion used when selecting one from a range of models with a different number of explanatory variables. The results of the "best" model (i.e. with the lowest BIC) are documented in Table 8.

In terms of product innovation, the 5-cluster solution (without any restrictions, i.e. incorporating all of the strategies $1-5$ ) minimised the BIC. In other words, the maximum heterogeneity allowed by the model used was found to provide the best fit. This suggests that differences between strategies are an important determinant of product innovation. Such differences appear to have less influence in the case of process innovation, where the model with two strategies (i.e. 3 restrictions: strategy 1 equals strategy 2; strategy 1 equals strategy 3; strategy 4 equals strategy 5) best fits the data. Nevertheless, by comparing the BIC of this model (for process innovation) with the BIC of that in Table 7, 2 strategies are better than no strategies at all. 
Table 8. Model with innovation strategy intercepts instead of initial innovation

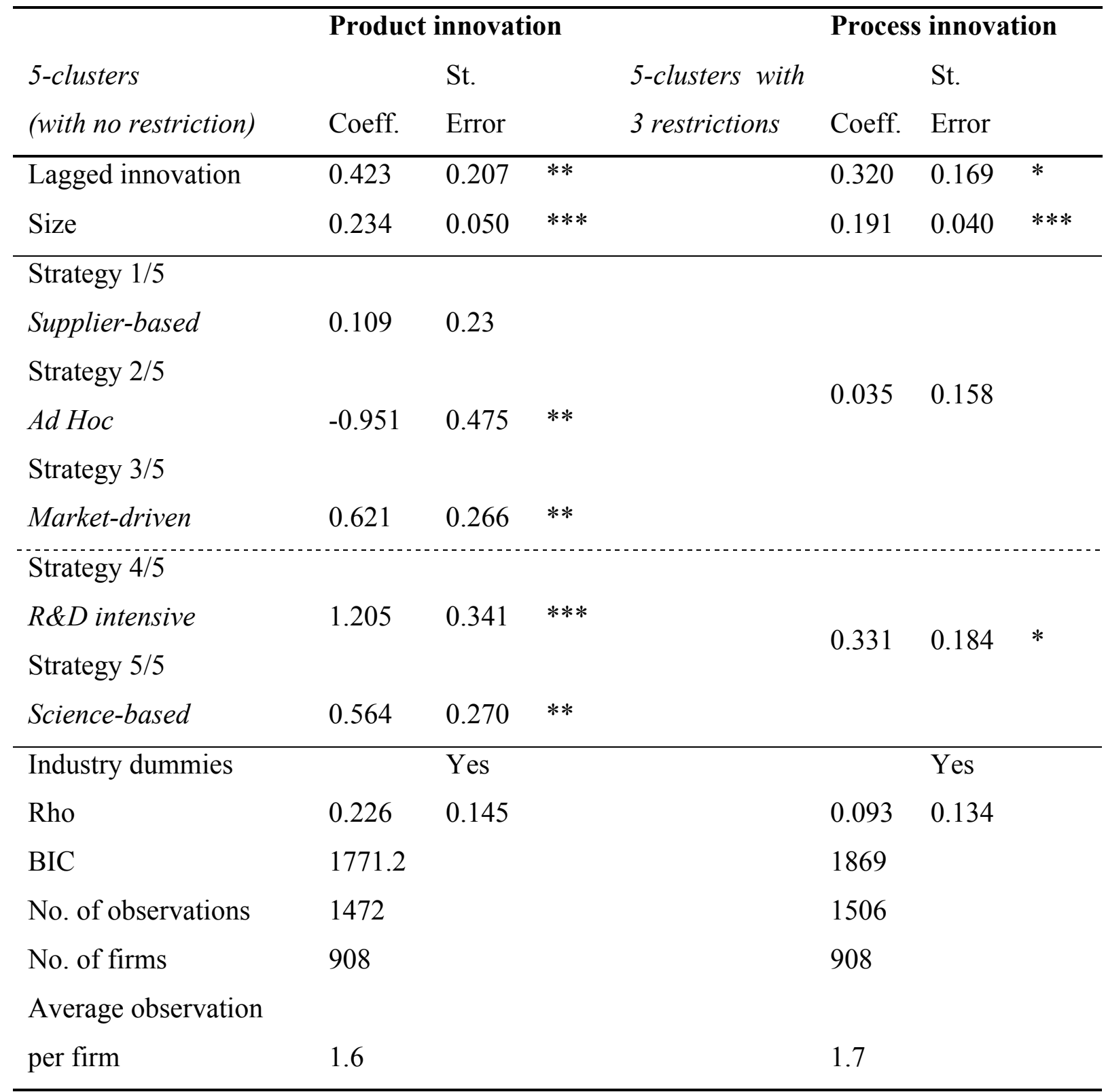

${ }^{*}, * *, * * *$ denote significance at the 10,5 and $1 \%$ level, respectively.

The results in Table 8 illustrate that both of the estimated coefficients for lagged innovation are still significant. Their value does not differ much from that in Table 7, which implies that the persistence results in Table 7 are robust to the inclusion of strategy variables which measure more firm heterogeneity than does the initial innovation. Despite the inclusion of the innovation strategies, the parts of the total variance explained by unobserved firm heterogeneity (rho) do not decline much. However, unobserved firm heterogeneity no longer contributes significantly to the product innovation equation. 
In the case of product innovation, which uses the 5-cluster solution without restrictions, the coefficient of the Supplier-based innovation strategy (mode 1/5) is not significant. Therefore, the firms in this group appear to be at the same baseline innovation probability as the firms which did not innovate in the initial period. The coefficient of the Ad hoc strategy (strategy 2/5), which includes the firms which innovate with minimal inputs, is negative and significant (in the case of product innovation). The negative coefficient indicates that these firms, ceteris paribus, are less likely to innovate than those identified as non-innovators in the initial period. This seems to suggest that this innovation strategy is a one-off innovation, i.e. once these firms innovate, they will not do it again in the next couple of years, because innovative activity is not a strategic element of their behaviour. This could be termed antipersistence.

The other three strategies for product innovation all show significant and positive coefficients, which indicates that firms with these innovation strategies are more likely to be innovators than those which did not initially innovate. Interestingly, the coefficients for these three innovation strategies differ from each other, with strategy 4/5 (R\&D intensive) yielding the highest one. This result supports the point made in the theoretical discussion, i.e. R\&D activity was positively related with innovation persistence due to the nature of sunk costs or the increased absorptive capacity related to this type of activity. Overall, the results clearly confirm the hypothesis that different types of innovation strategies lead to different probabilities of innovation, and that this tendency is persistent over the time-scale of the regressions in this exercise. Moreover, a weaker emphasis on the different dimensions of innovation strategies leads to less persistent innovation behaviour.

In terms of process innovation (applying the 5-cluster solution with 3 restrictions), the baseline innovation probability of the first three strategies (Supplier-based, Ad hoc and Market-driven) is not significant (i.e. statistically identical to non-innovators), and for the other two strategies, R\&D intensive and Science-based, it is positive, but not very high (the marginal effects will be presented and discussed later). This less-clear persistence in the case of process innovation is consistent with the results in Table 7 (basic model with no innovation strategies). 
Table 9. Estimations for high- and low-tech separately (only results with strongest persistence)

\section{Product innovation, high-tech}

(Basic Model)

St.

Coeff.

0.656

0.321

\begin{tabular}{|c|c|c|c|c|c|c|}
\hline & coeff. & Error & & coeff. & Error & \\
\hline Initial innovation & 0.593 & 0.319 & & & & \\
\hline Lagged innovation & 0.656 & 0.277 & $* *$ & 0.400 & 0.280 & \\
\hline Size & 0.321 & 0.093 & $* * *$ & 0.292 & 0.095 & $* * *$ \\
\hline $\begin{array}{l}\text { Strategy } 1 / 5 \text { Supplier-based } \\
\text { Strategy } 2 / 5 \text { Ad hoc }\end{array}$ & & & & -0.156 & 0.345 & \\
\hline Strategy 3/5 Market-driven & & & & 0.988 & 0.384 & $* * *$ \\
\hline $\begin{array}{l}\text { Strategy } 4 / 5 \text { R\&D intensive } \\
\text { Strategy } 5 / 5 \text { Science-based }\end{array}$ & & & & 1.120 & 0.363 & $* * *$ \\
\hline Industry dummies & & Yes & & & Yes & \\
\hline Rho & 0.258 & 0.100 & $*$ & 0.271 & 0.088 & $* *$ \\
\hline $\mathrm{BIC}$ & 397.3 & & & 391.4 & & \\
\hline No. of observations & 325 & & & 323 & & \\
\hline No. firms & 192 & & & 191 & & \\
\hline Average observation per firm & 1.7 & & & 1.7 & & \\
\hline
\end{tabular}

(5-clusters with 2 restrictions)

\section{Process innovation, low-tech}

(Basic Model)

St.

(5-clusters with 3 restrictions)

Coeff. Error $\quad$ Coeff. Error

Initial innovation

$0.059 \quad 0.177$

Lagged innovation

0.437

0.189

$* *$

0.432

0.186

Size

0.214
0.046

$0.190 \quad 0.044$

Strategy 1/5 Supplier-based

Strategy 2/5 Ad hoc

$-0.097$

0.170

Strategy 3/5 Market-driven

Strategy 4/5 R\&D intensive

Strategy 5/5 Science-based

$0.283 \quad 0.207$

Industry dummies

Yes

Yes

Rho

0.028

0.162

0.014

0.158

BIC

1416.4

1414.2

No. of observations

1175

1174

No. firms

720

719

Average observation per firm

1.6

1.6 
Raymond et al. (2006) found different results for persistence in high-tech and low-tech sectors, ${ }^{4}$ and this was also tested in the present study. Table 9 reports some estimations in which the model is estimated separately for high-tech and low-tech sectors. The full set of models is not documented (both types of innovation in both sectors), but instead, emphasis is placed on the cases which demonstrate a stronger persistence than those in Tables 7 and 8 . These are product innovation in high-tech, and process innovation in low-tech.

Product innovation in the high-tech sector appears to be very persistent if the innovation strategy variables are excluded (i.e. in the 'basic model'). In this case, a coefficient of about 0.66 was found for lagged innovation, which is higher than any coefficient in the previous tables. However, this appeared to be largely spurious, since the coefficient became nonsignificant and dropped to 0.4 when innovation strategies were included. In terms of process innovation, which is most persistent in the low-tech sector, no such spurious persistence was found. In fact, the innovation strategy variables all appeared to be non-significant in this case. The coefficient for lagged process innovation is about 0.1 higher than in Table 8 .

What do these results imply for the relevance of innovation strategies in explaining observed differences in the propensity to innovate between firms? In order to respond to this question, the implied marginal effects of the variables included in the estimates reported above need to be examined. The marginal effects, which were calculated using the predicted probit probabilities, are documented in Tables 10 and 11.

The overall impression is that the (observed) heterogeneity between firms (innovation strategies) plays an important role in explaining innovation probability, especially in explaining product innovation (see Tables $10 \& 11$ ). In the case of product innovation in all sectors (Table 10), firms which were initially in innovation strategy $4 / 5$ (R\&D intensive) have a $45 \%$ higher probability of innovation than those which did not innovate initially, across the entire time span of the regression. The effect of lagged innovation, i.e. the level of innovation persistence which is unexplained by differences in innovation strategies, is $16 \%$ (in the innovation strategies model), which is much lower than the innovation strategy $4 / 5$ effect. The $16 \%$ effect related to lagged innovation is comparable to the difference between

\footnotetext{
${ }^{4}$ High-tech and low-tech are defined along the lines of OECD (1999) classification. High-tech consists of chemicals, electrical products, machinery and equipment, plastics and vehicles industries. On the other hand, Low-tech consists of food, metals, non-metallic products, textiles, products not classified elsewhere, and wood.
} 
the marginal effects of innovation strategy $4 / 5$ and either innovation strategies $3 / 5$ (Marketdriven) or 5/5 (Science-based). However, it is smaller than the effect of either innovation strategies $3 / 5,4 / 5$ or $5 / 5$ individually, and also smaller than the absolute value of the innovation strategy $2 / 5$ effect (Ad hoc, which is $-28 \%$ ). Only in the case of process innovation is the effect of lagged innovation comparable in size to that of the innovation strategies (mode $4 / 5$ and mode $5 / 5$ in Table 10). In the low-tech sector (Table 11), the effect of lagged process innovation (about 15\%) is even larger than the effect of innovation strategies. As discussed earlier, this difference between the persistence of product and process innovation may be explained by the fact that process innovation is often undertaken based on learning-by-doing, which may involve less strategic decision-making and technological advancement.

Table 10. Marginal effects of the main variables in the model (initial innovation, innovation strategies)

\begin{tabular}{|c|c|c|c|c|c|c|}
\hline & $\begin{array}{l}\text { Marginal } \\
\text { Effect }\end{array}$ & $\begin{array}{l}\text { St. } \\
\text { Error }\end{array}$ & & $\begin{array}{l}\text { Marginal } \\
\text { Effect }\end{array}$ & $\begin{array}{l}\text { St. } \\
\text { Error }\end{array}$ & \\
\hline Basic model & \multicolumn{3}{|c|}{ Product innovation } & \multicolumn{3}{|c|}{ Process innovation } \\
\hline Initial innovation & 0.210 & 0.092 & $* *$ & 0.059 & 0.057 & \\
\hline Lagged innovation & 0.166 & 0.082 & $* *$ & 0.115 & 0.063 & $*$ \\
\hline Size & 0.105 & 0.020 & $* * *$ & 0.075 & 0.014 & $* * *$ \\
\hline \multicolumn{7}{|c|}{$\begin{array}{l}\text { Innovation Strategies } \\
\text { model }\end{array}$} \\
\hline Lagged innovation & 0.162 & 0.080 & $* *$ & 0.114 & 0.062 & * \\
\hline Size & 0.090 & 0.019 & $* * *$ & 0.067 & 0.014 & $* * *$ \\
\hline \multicolumn{7}{|l|}{ Strategy $1 / 5$} \\
\hline Supplier-based & 0.042 & 0.090 & & \multirow{4}{*}{0.012} & \multirow{4}{*}{0.056} & \\
\hline Strategy $2 / 5$ & & & & & & \\
\hline $\begin{array}{l}\text { Ad hoc } \\
\text { Strategy } 3 / 5\end{array}$ & -0.281 & 0.091 & $* * *$ & & & \\
\hline Market-driven & 0.244 & 0.102 & $* *$ & & & \\
\hline \multicolumn{7}{|l|}{ Strategy 4/5 } \\
\hline $\begin{array}{l}R \& D \text { intensive } \\
\text { Strategy } 5 / 5\end{array}$ & 0.445 & 0.103 & $* * *$ & \multirow[t]{2}{*}{0.122} & \multirow[t]{2}{*}{0.069} & \multirow[t]{2}{*}{$*$} \\
\hline Science-based & 0.221 & 0.105 & $* *$ & & & \\
\hline
\end{tabular}


Table 11. Marginal effects of the main variables in the model (high-tech, low-tech)

\begin{tabular}{|c|c|c|c|c|c|c|}
\hline & \multicolumn{4}{|c|}{ Product innovation, high-tech } & \multirow[b]{2}{*}{ St. } & \\
\hline & Marginal & St. & & Marginal & & \\
\hline & Effect & Error & & Effect & Error & \\
\hline Initial innovation & 0.223 & 0.12 & $*$ & & & \\
\hline Lagged innovation & 0.245 & 0.104 & $* *$ & 0.148 & 0.105 & \\
\hline Size & 0.118 & 0.034 & $* * *$ & 0.106 & 0.034 & $* * *$ \\
\hline Strategy 1/5 Supplier-based & & & & -0.058 & 0.131 & \\
\hline Strategy $2 / 5$ Ad hoc & & & & & & \\
\hline Strategy $3 / 5$ Market-driven & & & & 0.290 & 0.083 & $* * *$ \\
\hline $\begin{array}{l}\text { Strategy } 4 / 5 R \& D \text { intensive } \\
\text { Strategy } 5 / 5 \text { Science-based }\end{array}$ & & & & 0.369 & 0.102 & $* * *$ \\
\hline
\end{tabular}

\section{Process innovation, low-tech}

\begin{tabular}{llllllll} 
& $\begin{array}{l}\text { Marginal } \\
\text { Effect }\end{array}$ & $\begin{array}{l}\text { St. } \\
\text { Error }\end{array}$ & & $\begin{array}{l}\text { Marginal } \\
\text { Effect }\end{array}$ & $\begin{array}{l}\text { St. } \\
\text { Error }\end{array}$ \\
\hline Initial innovation & 0.02 & 0.06 & & & & & \\
Lagged innovation & 0.151 & 0.069 & $* *$ & 0.15 & 0.068 & $* *$ \\
Size & 0.072 & 0.015 & $* * *$ & 0.064 & 0.014 & $* * *$ \\
\hline
\end{tabular}

Strategy 1/5 Supplier-based

$\begin{array}{lll}\text { Strategy } 2 / 5 \text { Ad hoc } & -0.032 & 0.056\end{array}$

Strategy 3/5 Market-driven

Strategy $4 / 5 R \& D$ intensive

Strategy $5 / 5$ Science-based

$0.101 \quad 0.075$

$*, * *, * * *$ denote significance at the 10,5 and $1 \%$ level, respectively.

\section{Conclusions and Implications for Future Research}

An important issue in the recent literature on firm-level innovation is whether, and to what extent, firms which innovate once have a higher probability of innovating again in subsequent periods. Although this phenomenon, which is called 'innovation persistence', has been confirmed by many recent studies, none of which has ever empirically investigated why some firms (do not) persistently innovate, and this gap in knowledge is what motivates this study. Based on evolutionary theory and strategic management research, the present study 
proposes that firm heterogeneity in the form of stable strategic differences across firms can explain why they (do not) persistently innovate. Accordingly, the research question asked was, to what extent do differences in firms' innovation strategies affect their persistence of innovation?

Based on a methodology which combines factor analysis, cluster analysis, and a dynamic random effects probit model, and which extends the Wooldridge method (Wooldridge, 2005) normally used to examine innovation persistence, the study set out to explore this important question in a panel data framework. The results confirm the general finding in the literature that innovation is persistent at the firm level. The most interesting result in this paper is that observed and stable firm heterogeneity in the form of initial strategic differences across firms constitutes a key driving force behind a firm's probability to innovate over time. The econometric results suggest that the effects of innovation strategies are, in many cases, larger than the 'pure' effect of lagged innovation. This seems to suggest that innovation strategies provide an additional, and more important, source of innovation persistence than lagged innovation.

In addition, this study found that, although there appears to be a sign of persistence of product and process innovation, its significance and scale differ between these two types of innovation. This difference is along the lines of previous research, which has pointed out a distinction between the innovation characteristics of the two types. Differences were also found with regard to innovation persistence in high-tech and low-tech sectors. The results show that the low-tech sector is also persistent in innovation, but mainly in terms of process innovation.

The main contribution of this study to the literature is that it has extended prior research on innovation persistence with the argument that firms have different innovation strategies, and that such strategies constitute an important source of persistent innovative behaviour. Future studies may advance this line of research by showing how the effects of innovation strategies on innovation persistence differ across countries and industries. Future research could also try to better understand why and how firms innovate in one time period but not in subsequent time periods, and why and how firms are able to innovate at one point in time if they have not innovated in the past. This study proposes that initial innovation strategies have a long lasting 
effect on the way firms conduct innovation. Exploring these and similar questions holds a premise to better understanding firms' heterogeneity and sources of (persistent) innovation. 


\section{References}

Aldrich, H. (1999), Organizations evolving. SAGE: London.

Argyris, C. and Schon, D. (1978), Organizational Learning: A theory of action perspective. Addison-Wesley: MA.

Arora, A., Fosfuri, A. and Gambardella, A. (2001), 'Markets for Technology and their implications for corporate strategy', Industrial and Corporate Change, 10(2), 419-451.

Arrow, K. (1962), 'The Economic Implications of Learning by Doing', The Review of Economic Studies, 29(3), 155-173.

Arundel, A., Bordoy, C. and Kanerva, M. (2008), 'Neglected innovators: How do innovative firms that do not perform R\&D innovation?', Results of an analysis of the Innobarometer 2007 survey, No. 215, INNO-Metrics thematic paper.

Bodas Freitas, I.M., Clausen, T., Fontana, R. and Verspagen, B. (2008), 'Formal and informal external linkages and firms' innovation strategies: a cross-country comparison', TIK working paper on innovation studies no. 20081113.

Bottazzi, G., Secchi, A. and Tamagni, F. (2008), 'Productivity, profitability and financial performance', Industrial and Corporate Change, 17(4), 711-751.

Cabral. R. and Leiblein, M.J. (2001), 'Adoption of capital embodied process innovations in industries with learning by doing', Journal of Industrial Economics, 49(3), 269-280.

Castillejo, M., Rochina Barrachina, M.E., Sanchis Llopis, A. and Sanchis Llopis, J.A. (2004), 'A Dynamic Approach to the Decision to Invest in R\&D: The Role of Sunk Costs', Universidad Valencia.

Cefis, E. (2003), 'Is there persistence in innovative activities?' International Journal of Industrial Organization, 21(4), 489-515. 
Cefis, E. and Orsenigo, L. (2001), 'The persistence of innovative activities: A cross-countries and cross-sectors comparative analysis', Research Policy, 30(7), 1139-1158.

Chesbrough, H., Vanhaverbeke, W. and West, J. (eds.) (2006), Open Innovation: researching a new paradigm. Oxford University Press: Oxford.

Cohen, W. and Klepper, S. (1996), 'A reprise of size and R\&D', Economic Journal, 106, 925-951.

Cohen, W. and Levinthal, D. (1989), 'Innovation and Learning: the two faces of R\&D implications for the analysis of R\&D investment', Economic Journal, 99, 569-96.

Cohen, W. and Levinthal, D. (1990), 'Absorptive Capacity: a new perspective on learning and innovation', Administrative Science Quarterly, 35(1), 128-152.

Crepon, B. and Duguet, E. (1997), 'Estimating the Innovation Function from Patent Numbers: GMM on Count Panel Data', Journal of Applied Econometrics, 12(Special Issue: Econometric Models of Event Counts), 243-263.

Cyert, R.M. and March, J. (1963), A behavioural theory of the firm. Prentice-Hall: NJ.

Dosi, G. (1988), 'Sources, Procedures, and Microeconomic Effects of Innovation', Journal of Economic Literature, 26(3), 1120-1171.

Dosi, G., Gaffard, J.L. and Nesta, L. (2008), 'Schumpeterian themes on industrial evolution, structural change and their micro foundations: an introduction', Industrial and Corporate Change, 17(4), 601-609.

Duguet, E. and Monjon, S. (2004), 'Is innovation persistent at the firm level?: an econometric examination comparing the propensity score and regression methods', Université PanthéonSorbonne (Paris 1).

Duysters, G. and Hagedoorn, J. (1996), 'Internationalization of corporate technology through strategic partnering: an empirical investigation', Research Policy, 25(1), 1-12. 
Fagerberg, J. (2004) 'Innovation: A guide to the literature', in Fagerberg, J., Mowery, D.C. and Nelson, R.R. (eds.) The oxford handbook of innovation. Oxford University Press: Oxford.

Flaig, G. and Stadler, M. (1994), 'Success breeds success: the dynamics of the innovation process', Empirical Economics, 19, 55-68.

Geroski, P.A., van Reenen, J. and Walters, C.F. (1997), 'How persistently do firms innovate?', Research Policy, 26(1), 33-48.

Grant, R.M. (1996), 'Toward a knowledge-based theory of the firm', Strategic Management Journal, 17, 109-22.

Hall, B.H. (2002a), 'The assessment: Technology Policy', Oxford Review of Economic Policy, 18, 1-9.

Hall, B.H. (2002b), 'The financing of research and development', Oxford Review of Economic Policy, 18, 35-51.

Heckman, J. (1982), 'Heterogeneity and State Dependence', National Bureau of Economic Research, Inc.

Helfat, C.E. (1994), 'Evolutionary Trajectories in Petroleum Firm R\&D', Management Science, 40(12), 1720-1747.

Hoopes, D.G., Madsen, T. L. (2008), 'A capability-based view of competitive heterogeneity', Industrial and Corporate Change, 17, 393-426.

Jensen, M.B., Johnson, B., Lorenz, E. and Lundvall, B.-A. (2007), 'Forms of knowledge and modes of innovation', Research Policy, 36, 680-693.

Klepper, S. (1997), 'Industry Life Cycles', Industrial and Corporate Change, 6(1), 145-182. 
Laursen, K. and Salter, A. (2006), 'Open for innovation: The role of openness in explaining innovation performance among U.K. manufacturing firms', Strategic Management Journal, 27(2), 131-150.

Leiponen, A. and Helfat, C. (2010), 'Innovation objectives, knowledge sources, and the benefits of breadth', Strategic Management Journal, 31, 224-236.

Levitt, B. and March, J.G. (1988), 'Organizational Learning', Annual Review of Sociology, 14, 319-340.

Lundvall, B.-Å. (1988), 'Innovation as an Interactive Process: from User-Producer Interaction to National Systems of Innovation', in Dosi, G., Freeman, C., Nelson, R., Silverberg, G. and Soete, L. (eds.), Technical Change and Economic Theory. Pinter: London.

Malerba, F. and Orsenigo, L. (1996), 'Schumpeterian Patterns of Innovation are Technologyspecific', Research Policy, 25, 451-478.

Malerba, F. and Orsenigo, L. (1999), 'Technological entry, exit and survival: an empirical analysis of patent data', Research Policy, 28(6), 643-660.

Mowery, D.C. and Sampat, B.N. (2004), 'Universities in national innovation systems', in Fagerberg, J., Mowery, D.C. and Nelson, R.R. (eds.) The oxford handbook of innovation. Oxford University Press: Oxford.

Nelson, R.R. (1993), National innovation systems: a comparative study. Oxford University Press: Oxford.

Nelson, R.R. and Winter, S.G. (1982), An Evolutionary Theory of Economic Change. Harvard University Press: MA.

OECD (1999), Science, Technology and industry scoreboard: Benchmarking KnowledgeBased Economies. OECD: Paris. 
OECD/Eurostat (2005), Oslo Manual: guidelines for collecting and interpreting innovation data, OECD: Paris.

Penrose, E. (1959), The theory of the growth of the firm. Wiley: New York.

Peters, B. (2009) 'Persistence of innovation: stylized facts and panel data evidence', Journal of Technology Transfer, 34(2), $226-243$.

Pisano, G. (1997), The development factory: unlocking the potential of process innovation. Harvard Business Press: MA.

Raymond, W., Mohnen, P., Palm, F. and Van Der Loeff, S.S. (2006), 'Persistence of Innovation in Dutch Manufacturing: Is it Spurious?', CESifo Working Paper No. 1681.

Reichstein, T. and Salter, A. (2006), 'Investigating the sources of process innovation among UK manufacturing firms', Industrial and Corporate Change, 15(4), 653-682.

Rogers, M. (2004), 'Networks, Firm Size and Innovation', Small Business Economics, 22(2), 141-153.

Rosenberg, N. (1982), Insider the black box. Cambridge University Press: Cambridge.

Schumpeter, J. (1911), The Theory of Economic Development. Harvard University Press: Massachusetts.

Schumpeter, J. (1942), Capitalism, Socialism and Democracy. Routledge: London.

Smith, K. (2004), 'Measuring innovation', in Fagerberg, J., Mowery, D.C. and Nelson, R.R. (eds.) The Oxford Handbook of Innovation. Oxford University Press: Oxford.

Stuart, T. E. and Podolny, J.M. (1996), 'Local Search and the Evolution of Technological Capabilities', Strategic Management Journal, 17(Special Issue: Evolutionary Perspectives on Strategy), 21-38. 
Sutton, J. (1991), Sunk Costs and Market Structure. MIT Press: MA.

Teece, D.J., Pisano, G. and Shuen, A. (1997), 'Dynamic capabilities and strategic management', Strategic Management Journal, 18, 509-533.

Tushman, M.L. and Rosenkopf, L. (1992), 'Organizational determinants of technological change: towards a sociology of technological evolution', Research in Organizational Behavior, 14, 311-347.

Utterback, J.M. (1994), Mastering the dynamics of innovation: how companies can seize opportunities in the face of technological change. Harvard Business Press: MA.

Vega-Juardo, J., Gracia-Guitierrez, A. and Fernandez-De-Lucio, I. (2009), 'Does external knowledge sourcing matter for innovation? Evidence from the Spanish manufacturing industry', Industrial and Corporate Change, 18(4), 637-670.

Veugelers, R. and Cassiman, B. (1999), 'Make and buy in innovation strategies: evidence from Belgian manufacturing firms', Research Policy, 28, 63-80.

von Hippel, E. (1988), The sources of innovation. Oxford University Press: Oxford.

Vonortas, N.S. (1997), Cooperation in Research and Development. Kluwer Academic Press: MA.

Winter, S.G. (2003), 'Understanding Dynamic Capabilities', Strategic Management Journal, 24(10), 991-995.

Wooldridge, J. (2005), 'Simple solutions to the initial conditions problem in dynamic nonlinear panel data models with unobserved heterogeneity', Journal of Applied Econometrics, 20(1), 39-54. 